\title{
In-Vitro Alpha Amylase Inhibition and Antioxidant Activities of Leaves Extract of Sundanese Traditional Salad (Lalapan) from Indonesia
}

\author{
Leny Eka Tyas Wahyuni ${ }^{1}$, Hardinsyah Hardinsyah ${ }^{1 *}$, Budi Setiawan ${ }^{1}$ \\ ${ }^{1}$ Department of Community Nutrition, Faculty of Human Ecology, \\ IPB University, Bogor 16680, Indonesia
}

\begin{abstract}
This research aims to evaluate the $\alpha$-amylase inhibitory activity and antioxidant potential of leaves extract of Gandaria (Bouea macrophylla Griff.), Basil (Ocimum africanum Lour.), Pohpohan (Pilea melastomoides (Poir.) Wedd.), and Lettuce (Lactuca sativa L.) as common vegetables used in Sundanese traditional salad. Extraction methods used were traditional and maceration methods. Phytochemical screening was used to determine the phytochemical component qualitatively. Quantitative estimation of phenols (Folin-Ciocalteu method), flavonoids $\left(\mathrm{AlCl}_{3}\right.$ colorimetric assay), total antioxidant activity along with free radical scavenging activity (DPPH) was also carried out. Soluble starch was used as substrate for analysis of $\alpha$-amylase inhibitory activity, which is calculated by $\mathrm{IC}_{50}$ value. Phytochemical screening revealed the presence of phytochemical constituents like flavonoids, tannins, saponins, and polyphenols compound in both extraction methods. The results showed that the value of Total Phenolic Content (TPC), Total Flavonoid Content (TFC), antioxidant activity, and $\alpha$-amylase inhibitory in both extraction were significantly different for each leaves extracts $(p<0.05)$. The gandaria leaves extracted with maceration method had the highest value among the leaves analysed. The value of TPC, TFC, antioxidant activity were $364.56 \pm 65.97 \mathrm{mg}$ Gallic Acid Equivalent (GAE)/g extract, $70.2 \pm 10.54 \mathrm{mg}$ Quercetin $(\mathrm{QE}) / \mathrm{g}$ extract, and $35 \mu \mathrm{g} / \mathrm{ml}$ of $\mathrm{IC}_{50}$, respectively. The extract of gandaria maceration leaves exhibited significant $\alpha$-amylase inhibitory activity with an $\mathrm{IC}_{50}$ value of $60 \mu \mathrm{g} / \mathrm{ml}$. Various pharmacologically active compounds were found in the local vegetables, thus they can be rich sources of antioxidants and $\alpha$-amylase inhibitor activity. Hence, could be developed as vegetables based functional food products.
\end{abstract}

Keywords: $\alpha$-amylase, antioxidant, extraction methods, lalapan

\section{INTRODUCTION}

Diabetes mellitus is one of the diseases associated with an increased production of Reactive Oxygen Species (ROS) and impaired antioxidant defense system which result in oxidative damage (Kundusen et al. 2011). Diabetes mellitus is also characterized by hyperglycemia with disturbances of carbohydrate, lipid, and protein metabolism resulting from defect in insulin secretion and/ or insulin action (Keerthana et al. 2013). Thus reducing the postprandial hyperglycemia to lower glucose absorption using inhibitors of carbohydrate digesting enzymes is important (Bhuvaneshwari et al. 2014). The $\alpha$-amylase is an enzyme to break down starch into simple sugars, such as dextrin, maltotriosa, maltose, and glucose. Inhibiting the activity of $\alpha$-amylase enzyme is an effective method to control blood glucose (Alexander \& Maltodextrins 1992). Bioactive components found in herbal plants have shown good antioxidant and anti-diabetic properties (Kunyanga et al. 2012). As a bioactive compound, phytochemicals components such as tannins, phenols, and flavonoids have potential as inhibitors of the $\alpha$-amylase enzyme (Keerthana et al. 2013).

Blood glucose can be controlled by maintaining diet or dietary behavior, regular physical activity, maintaining body weight, and consuming vegetables that can help regulate blood glucose concentration effectively (Prabhakar \& Doble 2008). Lalapan (Sundanese traditional salad) is a raw and fresh vegetable dish commonly consumed by Sundanese in their daily meal. Pratama (2014), identified that the most common vegetables served as part of this traditional salad

\footnotetext{
"Corresponding Author: tel: +628129192259, email: hardinsyah@apps.ipb.ac.id
} 
were basil, pohpohan, and lettuce leaves. Another leave commonly consumed by Sundanese and is containing phytochemical compounds and health benefits is gandaria leaves (Lolaen et al. 2013; Rajan \& Bhat 2016). Previous research on antioxidant activity showed that the leaves of gandaria, basil, pohpohan, and lettuce have a high antioxidant activity (Andarwulan et al. 2010; Marwat et al. 2011; Gan \& Azrina 2016; Andina \& Musfirah 2017).

Considering the local availability and eating habit as well as findings on the potential health benefits of these leaves, it is important to explore the bioactive components potential for health. The result can inform the development of functional food based on locally available vegetables. The exploration of the leaves bioactive components should also consider the extraction method since the extraction method will affect the extracted compound. There are two extraction methods according to Verawati et al. (2016), they are the traditional and the laboratory or maceration methods. The traditional and the maceration methods are often used because they are relatively easy to conduct and do not require special tools. However, studies have shown that extraction processes using either the traditional or the maceration methods affected the total phenolic compound extracted from the leaves (Verawati et al. 2016). Therefore, it is imperative to identify the antioxidants and $\alpha$-amylase inhibitory activity of the Sundanese traditional salad (Lalapan) using both the traditional and the maceration extraction method.

\section{METHODS}

\section{Design, location, and time}

This experimental study used a randomized block design. The research activities included sample extraction, phytochemical screening, analysis of phenol and flavonoid, antioxidant activity, and inhibition of $\alpha$-amylase carried out in the Laboratory of Chemistry and Food Analysis, Department of Community Nutrition, IPB University, started from October-January 2019.

\section{Materials and tools}

The gandaria leaves was collected from Indonesia Institut of Science, Cibinong Bogor, while basil, pohpohan, and lettuce leaves were collected from Cigombong Agricultural Technology Park, Bogor. Specimens have been authenticated (No:2115a/IPH.1.01/ If.07/XII/2018) with the following results are Gandaria (Bouea macrophylla Griff.), Basil (Ocimum africanum Lour.), Pohpohan (Pilea melastomoides (Poir.) Wedd.), and Lettuce (Lactuca sativa L.).

Materials used for extraction and analysis were water for solvent, aquades, container, Wagner reagents, Liebermann-Burchard reagent, $\mathrm{HCl}$, methanol, $\mathrm{Mg}, \mathrm{KOH}, \mathrm{FeCl}_{3}$, gallic acid, FolinCiocalteu, $\mathrm{Na}_{2} \mathrm{CO}_{3}$, quercetin, $\mathrm{AlCl}_{3}, \mathrm{NaNO}_{2}$, $\mathrm{NaOH}$, vitamin C, 1.1-diphenyl-2-picrylhydrazyl (DPPH), porcine pancreatic $\alpha$-amylase enzyme concentration of $30 \mathrm{U} / \mathrm{mg}, 1 \%$ starch, phosphate buffer $\mathrm{pH}$ 6.9, 3.5-dinitrosalicylic solution (DNS), and potassium sodium tartrate.

The tools used for extraction and analysis were analytical scale, knive, board, filter cloth, Whatman 41, Buchner, blender, centrifuge, hot plate, and vacuum evaporator, erlenmeyer, test tubes, micro pipet, cuvettes, vortice, water bath, and UV-VIS spectrophotometers (Shimadzu UV160A, Kyoto, Japan).

\section{Data collection}

Sample preparation and extraction of leaves material. Sorted leaves were dried in shade at room temperature to choose the edible parts, leaves were washed in tap water and drained at room temperature, then leaves were chopped into small pieces to obtain a larger surface area. The extraction method used were traditional extraction and the maceration (laboratory). In the traditional extraction, samples were blended with water $(1: 10 \mathrm{w} / \mathrm{v})$, then centrifuged at 2,000 rpm (5 minutes) and the extract was filtered through a Whatman 41 using Buchner, and evaporated using a hot plate to obtain the liquid extract (Aisyah et al. 2015 modification). While in the maceration method, the sample was placed in a container and soaked in water. The container with its contents was sealed and kept for $2 \times 24$ hours with some stirring. Subsequently, the entire mixture then filtered by a filter cloth, then filtered again through Whatman 41 using Buchner. After filtration process, the macerate was evaporated at $60^{\circ} \mathrm{C}(65 \mathrm{kPa})$ using vacuum evaporator to obtain the dry extract (Verawati et al. 2016 modification).

The evaporation process of traditional extracts aimed to make it easier to control the 
concentration of the solution. Stock solution was done by weighing both extracts obtained from the two different method in the same amount. Thus, it was expected that the Total Dissolve solid (TDS) in the stock solution could be controlled despite the amount was not exactly the same due to the different sample form.

Phytochemical screening. The extracts were analyzed for the active phyto-constituents such as alkaloids, flavonoids, tannin, saponin, polyphenols, and terpenoid according to Harborne (1987). Alkaloids were analyzed by dissolving $2 \mathrm{ml}$ of sample in $2 \mathrm{ml}$ of $2 \% \mathrm{HCl}$, then heated for 5 minutes and filtered. The filtrate was added by 2-3 drops of Wagner reagent. The formation of white deposits shows the presence of alkaloid compounds. Flavonoids were analyzed by dissolving $2 \mathrm{ml}$ of sample in $2 \mathrm{ml}$ of methanol, then added with $\mathrm{Mg}$ and 5 drops of $37 \% \mathrm{HCl}$. The formation of red or orange colour indicates the presence of flavonoids. Tanin was analyzed by adding $2 \mathrm{ml}$ of sample with $\mathrm{FeCl}_{3}$ reagent. The formation of dark blue or blackish green colour indicates the presence of tannin. Saponin was analyzed by dissolving $2 \mathrm{ml}$ of sampel in a test tube, 10 drops of $\mathrm{KOH}$ were added and then heated in a water bath $\left(50^{\circ} \mathrm{C}\right)$ for 5 minutes and the solution was shaken for 15 minutes. The presence of a saponin is arranged with a steady foam and stable for 15 minutes. Polyphenols were analyzed by dissolving $2 \mathrm{ml}$ of sample in 10 $\mathrm{ml}$ distilled water and heated for 5 minutes, then filtered. The filtrate was added with 4-5 drops of $\mathrm{FeCl}_{3} 5 \%$. The formation of dark blue or blackish green colour indicates the presence of a phenols. Terpenoid was analyzed by adding $2 \mathrm{ml}$ of sample with $1 \mathrm{ml}$ of the Liberman-Burchard reagent. The formation of dark blue or blackish green colour indicates the presence of terpenoid compounds.

Estimation of total phenols. One $\mathrm{ml}$ of the extract solution was mixed with $1 \mathrm{ml}$ of FolinCiocalteu reagent, then $1 \mathrm{ml}$ of aqueous $10 \%$ $\mathrm{Na}_{2} \mathrm{CO}_{3}$ solution was added and vortexed. The mixture were allowed to stand for 90 minutes at room temperature. Absorbance was measured using a spectrophotometer at $765 \mathrm{~nm}$. The TPC was subsequently calculated using gallic acid as standard. Results obtained were expressed as $\mathrm{mg}$ GAE/g extract (Singleton \& Rossi 1965).

Estimation of total flavonoid. One $\mathrm{ml}$ of the extract solution dissolved in aquades (1:4), added $60 \mu \mathrm{l}$ of $5 \% \mathrm{NaNO}_{2}$ solution (incubated for
5 minutes), then added with $60 \mu 1$ of $10 \% \mathrm{AlCl}_{3}$ solution (incubated for 6 minutes). After that, added with $400 \mu \mathrm{l}$ of $10 \% \mathrm{NaOH}$ solution and then prepared by aquades to $2 \mathrm{ml}$. The mixture then was vortexed. The absorbance was measured using a spectrophotometer at $510 \mathrm{~nm}$. The TFC was calculated using quercetin as standard, and results obtained were expressed in term of QE/g extract (Sahu \& Saxena 2013).

DPPH free radical-scavenging assay. Antioxidant activity were determined based on percentage inhibition of DPPH radical and used vitamin $\mathrm{C}$ as a standard. The results obtained are presented by the $\mathrm{IC}_{50}$ value (concentration of the sample required to inhibit $50 \%$ of radical). The lower of $\mathrm{IC}_{50}$ value indicates that antioxidant activity is getting higher (Molyneux 2004). 750 $\mu l$ of extracts solution at different concentrations $(0.25 ; 0.5 ; 1 ; 2 ; 4 \mathrm{mg} / \mathrm{ml})$ were added to 750 $\mu 1$ of $0.2 \mathrm{mM}$ DPPH methanolic solution, the mixture was vortexed and left to stand in the dark for 30 minutes. Absorbance was measured at $517 \mathrm{~nm}$. The percentage of inhibition of DPPH radical was calculated according to the following equation:

$$
\% \text { Inhibition }=\left(\frac{\text { Abs control }- \text { Abs sample }}{\text { Abs control }}\right) X 100
$$

whereas, Abs control is the absorbance of DPPH solution without leave extracts.

In-vitro $\alpha$-amylase inhibitory assay. The analysis of $\alpha$-amylase inhibitory was conducted using the method described by Apostolidis et al. (2007) with slight modification. Acarbose as the pharmacological inhibitor was included as the positive control. Thirteen $\mu l$ of extracts solution at different concentrations $(0.078$; $0.156 ; 0.3125 ; 0.625 ; 1.25 ; 2.5 ; 5 ; 10 \mathrm{mg} / \mathrm{ml})$ were added to $94 \mu 1$ phosphate buffer ( $\mathrm{pH}$ 6.9) containing $\alpha$-amylase solution (30 U/mg). Then, $63 \mu 1$ of $1 \%$ soluble starch and $207 \mu 1$ phosphate buffer ( $\mathrm{pH}$ 6.9) were added to each tube at time intervals. The mixture was incubated at $37^{\circ} \mathrm{C}$ for 10 minutes. The reaction was stopped with a $313 \mu 1$ of DNS reagent. The test tube were then incubated at $100^{\circ} \mathrm{C}$ for 10 minutes and cooled to room temperature. The mixture was then diluted with $313 \mu \mathrm{l}$ of $40 \%$ potassium-sodium tartrate. Absorbance was measured at $540 \mathrm{~nm}$. The percentage of $\alpha$-amylase inhibitory was calculated according to the following equation:

$$
\text { \%Inhibition }=\left(\frac{\text { Abs control }-(\text { Abs sample }- \text { Abs blank })}{\text { Abs control }}\right) \times 100
$$


whereas, Abs control is the absorbance of solvent without sample, Abs blank is the absorbance of solvent without enzyme.

\section{Data analysis}

Data processing used the Microsoft Excel 2013 and Statistical Program Social Science (SPSS) version 16.0. Data analysis comprised of descriptive analysis, normality test, and different test. Different test were analyzed using Two Way ANOVA and Least Significance Differences (LSD) for differences of each samples $(p<0.05)$. Results were expressed as the mean \pm standard deviation.

\section{RESULT AND DISCUSSION}

\section{Phytochemical screening and quantification of secondary metabolite}

Qualitative phytochemical screening was aimed to identify any chemical components with bioactive compounds in the plant extracts, which can be further utilized (Aharoni \& Galili 2011). The qualitative analysis of the leaves extract confirmed the presence of flavonoids, tannins, saponins, and polyphenol compounds in both of the traditional and the maceration methods (Table $1)$.

The results of phytochemical screening showed different result from previous research, such as for mango (Mangifera indica) that is in the same family as gandaria (Anacardiaceae), basil (O. basilicum), pohpohan (Pilea trinervia), and lettuce (Lactuca sativa) leaves. However it is important to note that the leaves species as well as the extraction method used in these research were varied (Adham 2015; Dhital 2017; Guntara et al. 2016; Algfri et al. 2019). Thus, difference in the phytochemical components found in this study might be caused by several factors such as differences in the extraction steps, the polarity of solvent, and the species of plant. In addition, differences in the secondary metabolites component found in plants can be due to soil conditions where the plants are planted, such as soil moisture, water availability, temperature, $\mathrm{pH}$, land conditions, and light intensity (Vinolina 2014).

Phenolic compounds are the most widely distributed secondary metabolites and play an important role in growth regulators, have antioxidant, structural, attractant, signaling and protective functions (Babenko et al. 2019). The value of Total Phenolic Content (TPC) in both extraction methods were significantly different for each leaves extracts $(p<0.05)$ (Figure 1). The results also showed that phenolic content also significantly different between each of leaves species, thus extraction methods and the leaves species affected the total phenolic content.

The results showed that gandaria leaves extract with maceration had the highest total phenolic content, followed by gandaria from traditional extraction, lettuce, basil, and pohpohan with maceration extraction. The leaves extracted with traditional method showed lower results of TPC compared to the maceration. This is probably that maceration extract was evaporated using a vacuum evaporator at $60^{\circ} \mathrm{C}(65 \mathrm{kPa})$, so the water content evaporates more than in the traditional evaporation using a hot plate. The final result of maceration is dry extract obtained by drying the liquid extract until specific concentration according to the procedure. Drying is the process for removing solvents from the material to obtain powder/dry extract, while traditional extraction

Table 1. Phytochemical screening of leaves extract

\begin{tabular}{|c|c|c|c|c|c|c|c|c|}
\hline \multirow{2}{*}{ Phytochemicals } & \multicolumn{4}{|c|}{ Traditional } & \multicolumn{4}{|c|}{ Maceration } \\
\hline & Gandaria & Basil & Pohpohan & Lettuce & Gandaria & Basil & Pohpohan & Lettuce \\
\hline Alkaloids & - & - & - & - & - & - & - & - \\
\hline Flavonoids & +++ & ++ & ++ & ++ & +++ & ++ & ++ & ++ \\
\hline Tannin & +++ & ++ & + & + & +++ & ++ & + & + \\
\hline Saponins & + & + & ++ & + & + & ++ & +++ & + \\
\hline Polyphenols & +++ & ++ & + & + & +++ & ++ & + & + \\
\hline Terpenoids & - & - & - & - & - & - & - & - \\
\hline
\end{tabular}




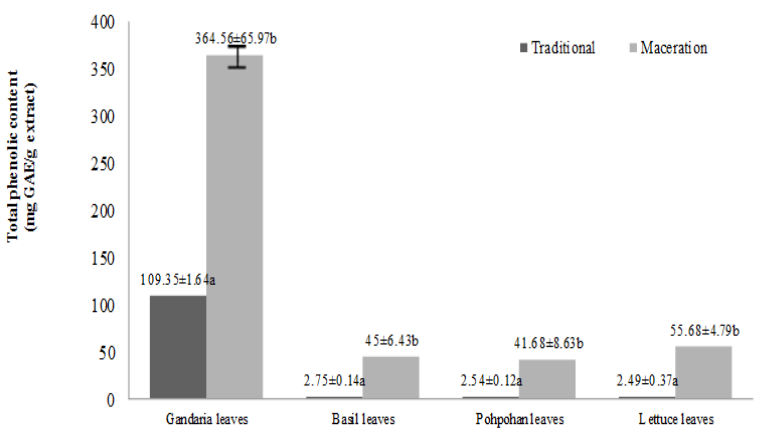

Figure 1. Total phenolic content of leave sextract. Different letters $(a-b)$ for each leaves are significantly different $(\mathrm{p}<0.05)$

is liquid extract so the concentration couldn't be controlled properly (Martin et al. 1961).

The evaporation process uses a vacuum so that it is good for food products that are sensitive to high temperatures. It can be processed to reduce their water content without damaging the physical condition and chemical content of the material (Supriatna 2008). In traditional extraction method, the extraction results were evaporated using a hot plate at $100^{\circ} \mathrm{C}$ without vacuum until the volume was reduced by $50 \%$ to get the liquid extract. While in the maceration, results were evaporated using an evaporator at $60^{\circ} \mathrm{C}$ so that the possibility of losing the water soluble nutrients will be even lower and the average of water evaporated was $98.8 \%$ by vacuum to get dry extract.

Verawati et al. (2016) reported that the total phenolic content of piladang water leaves extract with traditional extraction method $(S$. scutellariides $L$. Codd), evaporated by hot plate showed lower results $(77.31 \pm 0.21 \mathrm{mg}$ GAE$/ \mathrm{g}$ extract) compared to piladang maceration leaves extract (293.30 $\pm 0.13 \mathrm{mg} \mathrm{GAE} / \mathrm{g}$ extract). Difference in extraction method affected the extracted compound. Andina and Musfirah (2017) reported that the TFC of gandaria leaves extracted by maceration was $68.53 \pm 1.37 \mathrm{mg}$ GAE/g extract equal to our findings with the same method. It showed that the extraction method in different process affects the secondary metabolites content. In addition to extracted methods, differences in soil conditions or growing environment of plants will also affect the content of chemical compounds in these plants. The results of secondary metabolite content will show different on the same plant type if these plants are planted in different places (Yenni 2012).

Flavonoids are antioxidant compounds and naturally produced as secondary metabolites in plants. The Total Flavonoid Content (TFC) in different extraction methods were significantly different for each leaves extracts $(p<0.05)$ (Figure 2). The results also showed that flavonoid content also significantly different between each of the leaves extracts. It means that the extraction methods and leaves species affected the total flavonoid content of gandaria, basil, pohpohan, and lettuce leaves.

The maceration leaves extract contained higher TFC compared to the traditional leaves extract. The highest flavonoid content was found in gandaria from maceration method, followed by pohpohan, basil, and lettuce from maceration extracts. In contrast to the TPC, the gandaria traditional leaves extract showed was ranked fifth in TFC content.

Dhital's research (2017) showed that mango leaves as a plant from the same family with gandaria (Anacardiaceae), contained flavonoids of $55.63 \mathrm{mg}$ QE/g maceration extract. It means that Anacardiaceae family contains high flavonoids as antioxidants. Geographical location, time and climate differences, soil conditions, administration of pesticides or herbicides in plants are factors that can influence vegetable nutrients, antioxidants, and flavonoids (Andarwulan et al. 2010).

Overall, the TPC and TFC in maceration leaves extract had higher values than the traditional extraction. In the maceration method the sample or material to be extracted is soaked

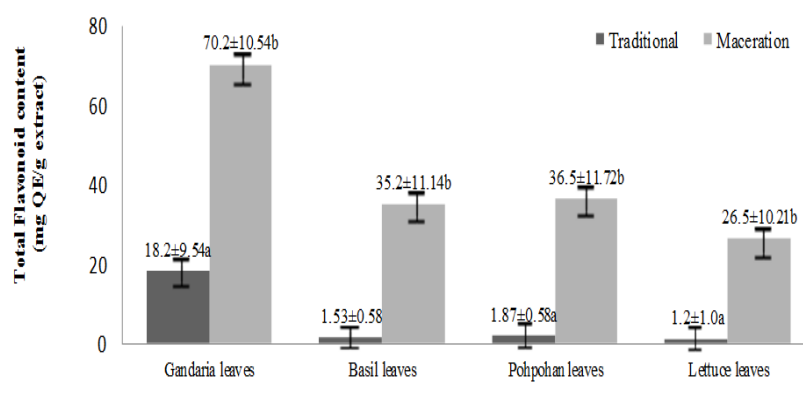

Figure 2. Total flavonoid content of leaves extract. Different letters (a-b) for each leaves are significantly different $(\mathrm{p}<0.05)$ 
in a closed container using a solvent and allowed to remain at room temperature with an adequate agitation. This process aims to soften or break down the plant cell walls so that phytochemical compounds can dissolve in solvents. During the immersion process, the cell wall and cell membrane of the sample will break because of the different pressure between the inside and outside of the cell and the content of secondary metabolites in the cell plasma will be dissolved in the solvent. In addition, the time of maceration can be adjusted according to the research purpose thus able to yield better result (Ibrahim \& Marham 2013).

The selection of solvents in the extraction process will also affect the effectiveness of the traceability based on solubility of natural material compounds in the solvent (Ibrahim \& Marham 2013). Solvents that have the same polarity as solutes dissolve the substance better. Water is one of the solvents that is often used in extraction processes with high polarity (Altemimi et al. 2017). High polarity solvents will also attract phytochemical components that also have high polarity levels such as phenols and flavonoids (Harborne 1987; Robinson 1995; Stankovic 2011).

The $\mathrm{IC}_{50}$ value of gandaria, basil, pohpohan, and lettuce leaves showed that all maceration leaves extracts had higher antioxidant activity compared to traditional leaves extracts, especially the gandaria leaves extract showed the highest value of antioxidant activity (Table 2). Vitamin $\mathrm{C}$ as a standard in this research had an $\mathrm{IC}_{50}$ value of $10 \mu \mathrm{g} / \mathrm{ml}$. A low value of antioxidant activity could be caused by the content of bioactive components of each sample with different extraction, and crude extract without partitioning used in this research is probably cause antioxidant activity to be of low value (Rahman et al. 2017). Andina and Musfirah (2017) reported that the antioxidant activity of gandaria leaves extract with maceration was high in antioxidant activity $\left(\mathrm{IC}_{50} 55.83 \mu \mathrm{g} / \mathrm{ml}\right)$. It means that gandaria showed the highest antioxidant potential.

Our results showed that antioxidant activity in both extraction were significantly different for each leaves extracts $(p<0.05)$. The results showed that antioxidant activity also significantly different between each of leaves extracts. It means that the extraction method and leaves affected the antioxidant activity of gandaria, basil, pohpohan, and lettuce leaves. Manggala $e t$ al. (2017) reported that the antioxidant activity of mango leaves extract with maceration method (Mangifera indica) was higher $\left(\mathrm{IC}_{50} 5.09 \mu \mathrm{g} / \mathrm{ml}\right.$ ) compared to the extract from reflux method ( $\mathrm{IC}_{50}$ $8.35 \mu \mathrm{g} / \mathrm{ml})$.

Analysis of $\alpha$-amylase inhibitory using acarbose as a positive control, showed very high inhibitory activity with $\mathrm{IC}_{50}$ value of 0.00045 $\mu \mathrm{g} / \mathrm{ml}$. Our results showed that gandaria and basil leaves extract with maceration have high $\alpha$-amylase inhibitory activity ( $\mathrm{IC}_{50} 60$ and $70 \mu \mathrm{g} /$ $\mathrm{ml}$ ) compared to other samples. Inhibitory action for $\alpha$-amylase enzyme in both extraction were significantly different for each leaves extracts $(p<0.05)$. The results showed that $\alpha$-amylase inhibitory activity also significantly different between each of the leaves species extracts. It means that the extraction methods and leaves affect the inhibitory activity of gandaria, basil, pohpohan, and lettuce leaves. Hence, we found that the leave extract which showed the highest $\alpha$-amylase inhibitory activity is the one that has the highest antioxidant activity, TPC, and TFC value. The extract was gandaria leaves with maceration extraction method (Table 3 ).

Bhuvaneshwari et al. (2014) showed that mature and tender mango leaves extracted by reflux had an $\mathrm{IC}_{50}$ values of 22.01 and $35.73 \mu \mathrm{g} /$ $\mathrm{ml}$, respectively. It showed that the Anacardiaceae family has very high of $\alpha$-amylase inhibitory activity. El-Beshbishy and Bahashwan (2011) reported that the inhibitory activity of $\alpha$-amylase enzyme in basil extract was indicated by $\mathrm{IC}_{50}$ value of $42.50 \mathrm{mg} / \mathrm{ml}$. The inhibitory activity is probably from the phenolic and flavonoid content of basil. Rahayuningsih (2014) reported that the

Table 2. Antioxidant activity of leaves extract

\begin{tabular}{|c|c|c|}
\hline \multirow{2}{*}{ Leaves extract } & \multicolumn{2}{|c|}{$\mathrm{IC}_{50}(\mu \mathrm{g} / \mathrm{ml})$} \\
\hline & Traditional & Maceration \\
\hline Vitamin $\mathrm{C}(10 \mu \mathrm{g} / \mathrm{ml})^{* *}$ & & \\
\hline Gandaria (B. macrophylla) & $649^{\mathrm{a}}$ & $35^{\mathrm{b}}$ \\
\hline $\operatorname{Basil}$ (O. africanum) & $>2,000^{\mathrm{a}}$ & $670^{\mathrm{b}}$ \\
\hline Pohpohan (P. melastomoides) & $>2,000^{\mathrm{a}}$ & $250^{\mathrm{b}}$ \\
\hline Lettuce (L. sativa) & $>2,000^{\mathrm{a}}$ & $183^{\mathrm{b}}$ \\
\hline
\end{tabular}


Table 3. $\alpha$-amylase inhibitory activity of leaves extract

\begin{tabular}{|c|c|c|}
\hline \multirow{2}{*}{ Leaves extract } & \multicolumn{2}{|c|}{$\mathrm{IC}_{50}(\mu \mathrm{g} / \mathrm{ml})$} \\
\hline & Traditional & Maceration \\
\hline Acarbose $(0.00045 \mu \mathrm{g} / \mathrm{ml})^{* *}$ & & \\
\hline Gandaria (B. macrophylla) & $163^{\mathrm{a}}$ & $60^{\mathrm{b}}$ \\
\hline Basil (O. africanum) & $>1,000^{\mathrm{a}}$ & $70^{\mathrm{b}}$ \\
\hline Pohpohan (P. melastomoides) & $>1,000^{\mathrm{a}}$ & $105^{\mathrm{b}}$ \\
\hline Lettuce (L. sativa) & $>1,000^{\mathrm{a}}$ & $117^{\mathrm{b}}$ \\
\hline
\end{tabular}

flavonoid content pohpohan (Pilea trinervia) leaves extract had an anti-hyperglycemia effect as indicated by glucose tolerance test in glucose induced diabetic rats. Lactucaxanthin (Lxn) of lettuce (Lactuca sativa) function as an inhibitor of carbohydrate digestive enzymes. Gopal et al (2017), reported that the inhibitory activity of the $\alpha$-amylase enzyme from $\mathrm{Lxn}$ had an $\mathrm{IC}_{50}$ value of $434.5 \mu \mathrm{g} / \mathrm{ml}$.

Maintaining blood glucose levels effectively can be obtained from natural sources such as from the bioactive compounds in vegetables that can function as $\alpha$-amylase inhibitor. Natural sources inhibitors, such as the one coming from the vegetables commonly consumed are highly recommended because they tend to not cause side effects when consumed (Tundis et al. 2010). In addition, Samudra et al. (2015) stated that secondary metabolites have high ability to inhibit the activity of the $\alpha$-amylase enzyme compared to the primary metabolites.

$\mathrm{Gu}$ et al. (2015) stated that phenolic acids and flavonoids can inhibit the activity of the $\alpha$-amylase enzyme. Phenolic acids and flavonoids will form covalent bonds with $\alpha$-amylase into quinones or lactones and react with nucleophilic groups, this causes changes in the activity of the $\alpha$-amylase enzyme (Tadera et al. 2006). Reaction of phenolic compounds and proteins be able to inhibit enzymatic activity including $\alpha$-amylase enzymes (Yanishlieva-Maslarova 2001). Polyphenols will form complexes with starch so that the $\alpha$-amylase enzyme cannot recognize the substrate (Himmah \& Handayani 2012).
The effect of flavonoids on the $\alpha$-amylase enzyme using enzymatic kinetic and fluorescence spectroscopy shows that flavonoids will form complexes with the $\alpha$-amylase enzyme. Flavonoids will be bound to the $\alpha$-amylase enzyme in a hydrophobic (Yuan et al. 2014). Flavonoids are also able to inhibit $\alpha$-amylase activity because they have the ability to form quinones with 4-oxopyrane (Adisakwattana \& Chanathong 2011). Flavonoids as antioxidants are able to prevent a decrease of $\beta$-pancreatic cells function progressively that caused by oxidative stress. Thus, it can reduce the occurrence of type 2 diabetes and can prevent the complications of diabetes in the long term (Song et al. 2005).

Within this research, the amount of Total Dissolve Solid (TDS) in samples with different extractions was not exactly the same thus it can be consider as a weakness in our methodology. However, the difference is due to the fact that different extraction methods will also show different sample forms. Therefore, to minimize this case, the researchers weighed all extracts after the evaporation process before preparing the stock solutions. So that the Total Dissolve Solid (TDS) of the extracts in different methods could still be controlled.

\section{CONCLUSION}

Sundanese traditional salad (Lalapan) contains various bioactive compounds and identified as potentially rich source of antioxidants and antihyperglycemia. The results of phytochemical screening confirms the presence of polyphenols, saponins, tannins, and flavonoids in gandaria leaves, basil, pohpohan, and lettuce. Extraction methods have a significant effect on TPC, TFC, antioxidant activity, and inhibition of $\alpha$-amylase enzymes. All maceration extracts have higher of TPC, TFC, antioxidants, and inhibition of $\alpha$-amylase compared to traditional extracts. The leave extract with the highest TPC, TFC, antioxidants, and inhibition of $\alpha$-amylase activity is gandaria leaves extract with maceration method.

Based on the results of the research, further analysis is needed regarding bioactive compounds in Lalapan with different extraction methods using High Performance Liquid Chromatography (HPLC). Pra-clinical and clinical research is needed to determine the benefits of its bioactive 
compounds. Furthermore, Lalapan as source of antioxidant can be developed as vegetable-based functional food products for antihyperglycemia.

\section{ACKNOWLEDGEMENT}

We thank to Ministry of Research, Technology, and Higher Education for providing the research funds so that this study to be part of the main research entitled "Eating Culture, Antioxidant Potential, and Antihyperglycemia of Gandaria Leaves (Bouea macrophylla Griff.)" with contracts number 1750/IT3.11/PN/2018 and Dr Joeni Setijo Rahajoe as botanists from Biology Research Center, Cibinong Bogor.

\section{AUTHOR DISCLOSURES}

The authors have no conflict of interest.

\section{REFERENCES}

Adham AN. 2015. Comparative extraction methods, phytochemical constituents, fluorescence analysis and HPLC validation of rosmarinic acid content in Mentha piperita, Mentha longifolia, and Osimum basilicum. J Pharmacogn Phytochem 3(6):130-139.

Adisakwattana S, Chanathong B. 2011. $\alpha$-glucosidase inhibitory activity and lipidlowering mechanisms of Moringa oleifera leaf extract. Eur Rev Med Pharmacol Sci 15(7):803-808.

Aharoni A, Galili G. 2011. Metabolic engineering of the plant primary-secondary metabolism interface. Curr Opin Biotechnol 22(2): 239-244. https://doi.org/10.1016/j. copbio.2010.11.004.

Aisyah Y, Rasdiansyah, Muhaimin. 2015. Pengaruh pemanasan terhadap aktivitas antioksidan pada beberapa jenis sayuran JTIP Indonesia 6(2):28-32. doi:10.17969/ jtipi.v6i2.2063.

Alexander R, Maltodextrins R. 1992. Production, Properties and Applications. In: Schenk F, Hebeda R (Ed.) Starch Hydrolysis Products. New York (USA): Worldwide Technology.

Algfri SK, Kaid AA, Munaiem RT. 2019. Phytichemical and antioxidant studies of some green leafy vegetables consumed in Yemen as salad. J Med Plants Stud 7(1):22-28.

Altemimi A, Lakhssassi N, Baharlouei A, Watson DG, Lightfoot DA. 2017. Phytochemicalls: Extraction, isolation, and identification of bioactive compounds from plant extracts. Plants 6(4):1-23. https://doi.org/10.3390/ plants6040042.

Andarwulan N, Batari R, Sandrasari DA, Bolling B, Wijaya H. 2010. Flavonoid content and antioxidant activity of vegetables from Indonesia. Food Chem 121(4):1231-1235. doi:10.1016/j.foodchem.2010.01.033.

Andina L, Musfirah Y. 2017. Total phenolic content of cortex and leaves of ramania (Bouea macrophylla Griffith) and antioxidant activity assay by DPPH method. Res J Pharm Biol Chem Sci 8(1):134-140.

Apostolidis E, KwonYI, Shetty K. 2007. Inhibitory potential of herb fruit and fungal-enriched cheese against key enzymes linked to type 2 diabetes and hypertension. Innov Food Sci Emerg Technol 8(1):46-54. https://doi. org/10.1016/j.ifset.2006.06.001.

Babenko LM, Smirnov OE, Romanenko KO, Trunova OK, Kosakivska IV. 2019. Phenolic compounds in plants: Biogenesis and functions. Ukr Biochem J 91(3): 1-18. doi: https://doi.org/10.15407/ ubj91.03.005.

Bhuvaneshwari, Khanam S, Devi K. 2014. In vitro enzyme inhibition studies for antidiabetic activity of mature and tender leaves of Mangifera indica var totapuri. J Microbiol Biotechn 3(3):36-41.

Dhital KS. 2017. Phytochemical screening and antioxidant activities of Mangifera indica leaves grown in temperate region of the Nepal. J Pharmacogn Phytochem 6(3):205-209.

El-Beshbishy HA, Bahashwan SA. 2011. Hypoglycemic effect of basil (Ocimum basilicum) aqueous extract is mediated through inhibition of $\alpha$-glucosidase and $\alpha$-amylase activities: An in vitro study. Toxicol Ind Health 28(1):42-50. https:// doi.org/10.1177/0748233711403193.

Gan YZ, Azrina A. 2016. Antioxidant properties of selected varieties of lettuce (Lactuca sativa L.) commercially available in Malaysia. Int Food Res J 23(6):2357-2362. 
Gopal SS, Lakshmi MJ, Sharavana G, Sathaiah G, Sreerama YN, Baskaran V. 2017. Lactucaxanthin - a potential antidiabetic carotenoid from lettuce (Lactuca sativa) inhibits $\alpha$-amylase and $\alpha$-glucosidase activity in vitro and in diabetic rats. Food Funct 8(3):1124-1131. doi:10.1039/ C6FO01655C.

Gu C, Zhang H, Putri CY, Ng K. 2015. Evaluation of $\alpha$-glucosidase inhibitory activity of flavonoids. Int J Food Nutr Sci 2(2):174179. doi: 10.15436/2377-0619.15.042.

Guntara A, Lukmayani Y, Kodir RA. 2016. Identifikasi senyawa flavonoid pada ekstrak dan fraksi dari daun pohpohan (Pilea trinervia Wight.). Prosiding Farm 2(2):749-754.

Harborne JB.1987. Metode Fitokimia: Penuntun Cara Modern Menganalisis Tumbuhan. Edisi Kedua. Bandung (ID): ITB.

Himmah LF, Handayani W. 2012. Pengaruh ekstrak teh hijau dalam pembuatan beras dengan IG rendah. J Universitas Negeri Jember 1(1):1-3.

Ibrahim S, Marham S. 2013. Teknik Laboratorium Kimia Organik. Yogyakarta: Graha Ilmu.

Keerthana G, Kalaivani MK, Sumathy A. 2013. In vitro alpha amylase inhibitory and antioxidant activities of ethanolic leaf extract of Croton bonplandianum. Asian J Pharm Clin Res 6(4):32-36.

Kundusen S, Gupta M, Mazumder UK, Haldar PK, Saha P, Bhattacharya S, Kar B, Bala A. 2011. Antihyperglycemic effect and antioxidant property of Citrus maxima leaf in streptozotocin-induced diabetic rats. Diabetol Croat 40(4):113-120.

Kunyanga CN, Imungi JK, Okoth MW, Biesalski HK, Vadivel V. 2012. Total phenolic content, antioxidant and antidiabetic properties of methanolic extract of raw and traditionally processed Kenyan indigenous food ingrendients. LWT-Food Sci Technol 45(2):269-276. https://doi.org/10.1016/j. lwt.2011.08.006.

Lolaen LA, Fatimawali, Citraningtyas G. 2013. Uji antioksidan kandungan fitokimia jus buah gandaria (Bouea macrophylla Griffith). Pharmacon 2(2):1-7.

Manggala EA, Purwanti L, Syafnir L. 2017. Perbandingan aktivitas antioksidan ekstrak etanol daun mangga bapang (Mangifera indica L.) dengan metode ekstraksi maserasi dan refluks. Prosiding Farmasi 3(1):67-71.

Martin EW, Cook EF, Leuallen EE, Osol, Athur, Tice LF, Meter, Van CT. 1961. Remington's Practice of Pharmacy. Easton (USA): Mack Publishing Company.

Marwat SK, Fazal-Ur-Rehman, Khan MS, Ghulam S, Anwar N, Mustafa G, Usman K. 2011. Phytochemical constituents and pharmacological activities of sweet basil Ocimum basilicum L. (Lamiaceae). Asian J Chem 23(9):3773-3782.

Molyneux P. 2004. The use of the stable free radical diphenylpicrylhydrazyl (DPPH) for estimating antioxidant activity. J Sci Technol 26(2):211-219.

Prabhakar PK, Doble M. 2008. A target based therapeutic approach toward diabetes mellitus using medicinal plants. Curr Diabetes Rev 4(4):291-308.

Pratama AP. 2014. Menejemen penyelenggaraan makanan di restoran sunda di kota Bogor [Undegraduate Thesis]. Bogor: IPB University.

Rahayuningsih N. 2014. Uji aktivitas antidiabetes ekstrak etanol daun pohpohan (Pilea trinervia Wight.) pada mencit putih jantan galur Swiss Webster. Jurnal Kesehatan Bakti Tunas Husada 12(1):1-9. http:// dx.doi.org/10.36465/jkbth.v12i1.60.

Rahman DR, Rimbawan, Madanijah S, Purwaningsih S. 2017. Potensi selada air (Nasturtium Officinale R. Br) sebagai antioksidan dan agen antiproliferasi terhadap sel MCF-7 secara in vitro. J Gizi Pangan 12(3):217-224. http://dx.doi. org/10.25182/jgp.2017.12.3.217-224.

Rajan NS, Bhat R. 2016. Antioxidant compounds and antioxidant activities in unripe and ripe kundang fruits (Bouea macrophylla Griffith). Fruits 71(1):41-47. https://doi. org/10.1051/fruits/2015046.

Robinson T. 1995. Kandungan Organik Tumbuhan Tinggi. Bandung: ITB.

Sahu R, Saxena J. 2013. Screening of total phenolic and flavonoid content in conventional and non-conventional species of Curcuma. J Pharmacogn Phytochem 2(1):176-179.

Samudra AG, Nugroho AE, Husni A. 2015. Aktivitas Inhibisi $\alpha$-amilase ekstrak karagenan dan senyawa polifenol dari 
Eucheuma denticulatum. Media Farmasi 12(1):83-92. http://dx.doi.org/10.12928/ mf.v12i1.3023.

Singleton VL, Rossi JA. 1965. Calorimetry of total phenolics with phosphomolybdicphosphotungstic acid reagents. Am J Enol Vitcult 16(1):144-158.

Song Y, Manson JE, Buring JE, Sesso HD, Liu S. 2005.Association of dietary flavonoids with risk of type 2 diabetes and markers of insulin resistance and systemic inflammation in women: A prospective study and cross sectional analysis. J Am Coll Nutr 24(5): 376-384. https://doi.org/ 10.1080/07315724.2005.10719488.

Stankovic MS. 2011. Total phenolic content, flavonoid concentration and antioxidant activity of Marrubium peregrinum L. extracts. Kragujevac J Sci 33(2011):63-72.

Supriatna A. 2008. Uji performansi dan analisa teknik alat evaporator vakum [Undergraduate Thesis]. Bogor: IPB University.

Tadera K, Minami Y, Takanatsu K, Matsuoka T. 2006. Inhibition of $\alpha$-glucosidase and $\alpha$-amylase by flavonoids. J Nutr Sci Vitamol. 52(2):149-153. https://doi. org/10.3177/jnsv.52.149.

Tundis R, Loizzo MR, Menichini F. 2010. Natural products as alpha-amylase and alpha-glucosidase inhibitors and their hypoglycaemic potential in the treatment of diabetes: An update. Mini Rev Med Chem 10(4):315-331. https://doi. org/10.2174/138955710791331007.

Verawati, Arel A, Arfanisa R. 2016. Pengaruh perbedaan metode ekatraksi terhadap kandungan fenolat total ekstrak daun piladang (Solenostemon scutellariides L. Codd). Scientia 6(2):79-83. doi: http:// dx.doi.org/10.36434/scientia.v6i2.47.

Vinolina NS. 2014. Peningkatan produksi centellosida pada pegagan (Centella asiatica) melalui pemberian fosfor dan metil jasmonat dengan umur panen yang berbeda [Dissertation]. Sumatera Utara: Universitas Sumatera Utara.

Yanishlieva-Maslarova NV. 2001. Inhibiting Oxidation. In: Pokorny J, Yanishlieva $\mathrm{N}$, Gordon MH. Antioxidants in Food: Practical Applications. Cambridge: Woodhead Publishing Limited.

Yenni. 2012. Ameliorasi tanah sulfat masam potensial untuk budidaya tanaman bawang merah (Allium ascalonicum L.). Jurnal Lahan Suboptimal 1(1): 40-49. https://doi. org/10.33230/JLSO.1.1.2012.3.

Yuan E, Liu B, Wei Q, Yang J, Chen L, Li Q. 2014. Structure activity relationship of flavonoids as potent alpha-amylase inhibitors. Nat Prod Commun 9(8):1173-1176. https:// doi.org/10.1177/1934578X1400900829. 